\title{
Information behaviour and expectations of veterinary researchers and their requirements for academic library services
}

\author{
Marguerite A. Nel ${ }^{*}$
}

Department of Information Science, University of Pretoria, IT Building 6-65, Lynnwood Road, Pretoria 0002, South Africa

*Corresponding author. Tel.: + 2712529 8474; fax: + 2712362 5181. marguerite.nel@up.ac.za Ina Fourie

Department of Information Science, University of Pretoria, IT Building 6-65, Lynnwood Road, Pretoria 0002, South Africa

Tel.: + 2712420 5216; fax: + 2712362 5181.ina.fourie@up.ac.za

\section{ABSTRACT}

Increased pressure for quality research at South African universities, and limited research done on the information needs of veterinary science researchers and the role of veterinary libraries supporting them, motivated a case study at the Faculty of Veterinary Science, University of Pretoria (South Africa). The study aimed to determine what the information needs, information seeking behaviour and information use behaviour of veterinary researchers are, and how these needs are being met by the library. Quantitative and qualitative data were collected from researchers as well as information specialists by means of questionnaires, focus group interviews and a citation analysis. Findings and recommendations are based on descriptive statistical analysis of the quantitative data and thematic analysis of the qualitative data. The study found that the information needs of researchers are influenced by the research environment and expectations for research output. Most needs for information and support services are met. Collection building practices, library space, and awareness of services offered by information specialists need attention. Findings reveal considerable gaps between researchers' expectations from information specialists and their own perceptions of roles to fulfil. The paper contributes to the limited literature on the information behaviour of veterinary researchers and library services supporting their needs. 
Keywords: Veterinary researchers; information needs; information seeking behaviour; information use behaviour; researchers; veterinary libraries

\section{INTRODUCTION}

The Faculty of Veterinary Science at the University of Pretoria is the only veterinary faculty in South Africa and one of 46 in Africa. Research in the Faculty has an impact on the health of humans and animals locally as well as globally (Swan \& Kriek, 2009). All higher education institutions in South Africa are under pressure to improve their research output and international research visibility (Kahn, 2011; Nel, 2015; Sooryamoorthy, 2013). Individual researchers are peer-rated according to the National Research Foundation (NRF) rating system which has become a prestige mechanism for research intensive institutions in South Africa (Pouris, 2007). The NRF is a South African institution responsible for facilitating the peer rating of researchers and especially academics at higher education institutions, as well as for promoting research through grants, etc. (NRF website).

The Veterinary Faculty is supported by services of the Jotello F Soga Library (hereafter referred to as the Library) with six full-time and two part-time employees, of whom five are professional librarians and three are library assistants. With an increase in expectations for the quantity and quality of research output and international visibility of researchers, it is expected that there might also be an increase in needs for support from the Library and information specialists (the term used by the Library; the literature often also refers to librarians). With this in mind a study guided by the following research question was launched:

What are the information needs, information seeking behaviour and information use behaviour of researchers at the Faculty of Veterinary Science, University of Pretoria, and how are these needs being met by the information support delivered by the Jotello F Soga Library?

Several issues were pursued: a literature review on the pressure in South Africa for internationally competitive research output and international visibility of researchers; a citation analysis of the research output of veterinary researchers in the Faculty; and a literature review of the information needs and information behaviour of 
veterinarians (students, practitioners and researchers). Data was collected through a survey with veterinary researchers (masters and doctoral students and faculty / academic staff) and three information specialists from the Library. Although the study focused on a specific library, the purpose of the paper is to show the value of using a diversity of methods of data collection to plan and adapt library services according to environmental pressures, the realities of research output, the needs of the users (i.e. the researchers), and the opinion and perceptions of the library staff providing the services and support.

The research design and methods, findings for each of the issues, and recommendations for a framework to explore the services of veterinary libraries that meet with the information needs, information behaviour and expectations of veterinary researchers, and input from librarians are discussed in this paper. The value of the findings for studies of information behaviour aimed at the design of information systems and services is also noted.

\section{BACKGROUND AND SCOPE OF THE STUDY}

The study was conducted between 2011 - 2014, with the survey and empirical data collection between October 2013 and February 2014. At the time of the study the Library was offering core services such as interlibrary loans and information resource access services (including delivering online services through a website with access to a collection of multi-disciplinary electronic books, journals and databases, as well as digital and institutional repositories, electronic theses and dissertations, subject portals, library blogs, online tutorials) and library liaison and instruction services to the Faculty as well as information support to veterinary practitioners. Considering the pressure on institutions of higher education in South Africa, it was not clear if these services were fully meeting the information needs and expectations of the researchers, and how the Library's services and the roles of the information specialists need to be adapted.

Literature searches in core databases from library and information science as well as those covering veterinary science, health, and agriculture were searched (Library and Information Science Abstracts (ProQuest), ScienceDirect, Library, Information Science \& Technology Abstracts (EBSCOHost), Medline (EBSCOHost), CAB 
Abstracts (ISI) and Google Scholar) and found limited research reports on the information needs and information behaviour of veterinarians and library services to veterinarians. A study of the status quo at the Jotello F Soga Library and a core user group - veterinary researchers in the Faculty of Veterinary Science (University of Pretoria) - thus seemed timely and appropriate.

From the subject literature (Case, 2012; Courtright, 2007; Leckie, Pettigrew \& Sylvain, 1996; Musoke, 2008; Wilson, 1981, 2006) it was clear that contexts, including the country and institutional environment, as well as the situation in which researchers find themselves, can have an important impact on needs for information, and thus also library services. With regard to context it was therefore decided to review the research situation and expectations from researchers in South Africa, as well as the research output of the Faculty. The latter was done by means of a citation analysis. Although a fair amount of information is available on library services to researchers (Brophy, 2008; Fourie, 2004; Wakeham \& Garfield, 2005; Webb, Gannon-Leary \& Bent, 2007), information specialists cannot use these alone to guide decisions on their role and the services to render. A survey was thus conducted with researchers in the Faculty as well as with the three information specialists dedicated to serving the information needs of researchers. The first author of this paper is also a member of this library, although not directly assigned to offering support to Faculty researchers.

Although this paper is presented as a case study at the University of Pretoria and from the South African perspective, it has relevance beyond this institution and country. Other academic libraries also face institutional and country specific pressures, they are also required to assess research impact and they need to offer relevant services to users including institutional staff and students. The diversity of methods reported in this paper can guide similar projects by other academic libraries.

\section{RESEARCH LANDSCAPE IN SOUTH AFRICA AND RESEARCH OUTPUT OF THE FACULTY OF VETERINARY SCIENCE}

Veterinary researchers fulfil their research and tasks against the background of what their country and the international scholarly community expect from researchers. 
South Africa, like many other countries, is experiencing an increase in demands for quality and quantity, and the visibility of research output. According to Courtright (2007, p. 273) it is important to examine information practices as part of a "process that takes place within specified situations and contexts". (The term "information practices" is often used interchangeably with "information behaviour", although there are differences in their meaning (Savolainen, 2007)). This section briefly considers the South African research landscape as well as the status quo of research output from the Faculty of Veterinary Science (University of Pretoria).

Research and knowledge production in South Africa are high-priority strategies for the South African government (Jeenah \& Pouris, 2008; Sooryamoorthy, 2013). One of the initiatives developed by the South African Department of Higher Education and Training (DoHET) is to link research funding and remuneration (i.e. government subsidy) for higher education institutions to the quality and quantity of research output (Diab \& Gevers, 2009; Habib \& Morrow, 2006; Jeenah \& Pouris, 2008; Kahn, 2011). This requires researchers to publish in journals approved by the DoHET. These journals are referred to as accredited journals. They are peer-reviewed journals meeting with criteria set by the DoHET for high quality reputable local journals. The Thomson Reuters (ISI) Web of Science list of indexed journals is accepted by the DoHET as accredited journals that qualify for government subsidy. It is also often used in bibliometric studies to determine the research ranking of institutions and countries. The scheme of the South African government subsidy to universities based on publication in accredited journals encourage researchers to publish in accredited journals and especially international journals appearing in the ISI list (Vaughan, 2008).

For further encouragement a system for peer review and rating were introduced by the National Research Foundation (NRF). The NRF is a South African initiative that facilitates the peer rating of researchers on various levels, ranging from category $A$ (top international scholars in their field) to $C$ (established researchers with a sustained research productivity record), as well as categories $\mathrm{P}$ and $\mathrm{Y}$ for younger and upcoming researchers. This system allows researchers to benefit directly in the form of project-related research funding and support for postgraduate students (NRF website). 
Apart from rated researchers receiving incentive funding and research grants, the number of rated researchers also adds to the prestige of the institution, as well as international visibility and acknowledgement of institutional research activities (Diab \& Gevers, 2009; Pouris, 2007; Vaughan, 2008).

Meeting national goals, as well as the goals of the University of Pretoria is a priority at the Faculty of Veterinary Science (Swan \& Kriek, 2009). A citation analysis of the 2012 and 2013 research output of the Faculty was thus conducted to investigate whether there had been an increase in publication quantity as well as publication quality (impact factors of journals), whether there was an improvement in international visibility (publication in international journals), and to reveal choices of journals for publication.

Figures 1 and 2 indicate the publication output as well as the average impact factor per journal respectively according to Faculty departments. Publications from most departments increased and an overall increase of 109 articles between 2012 and 2013 is seen in Figure 1. There was also an improvement in the journal impact factors for most departments as well as an overall tendency for the Faculty as a whole to publish in higher impact factor journals (Figure 2).

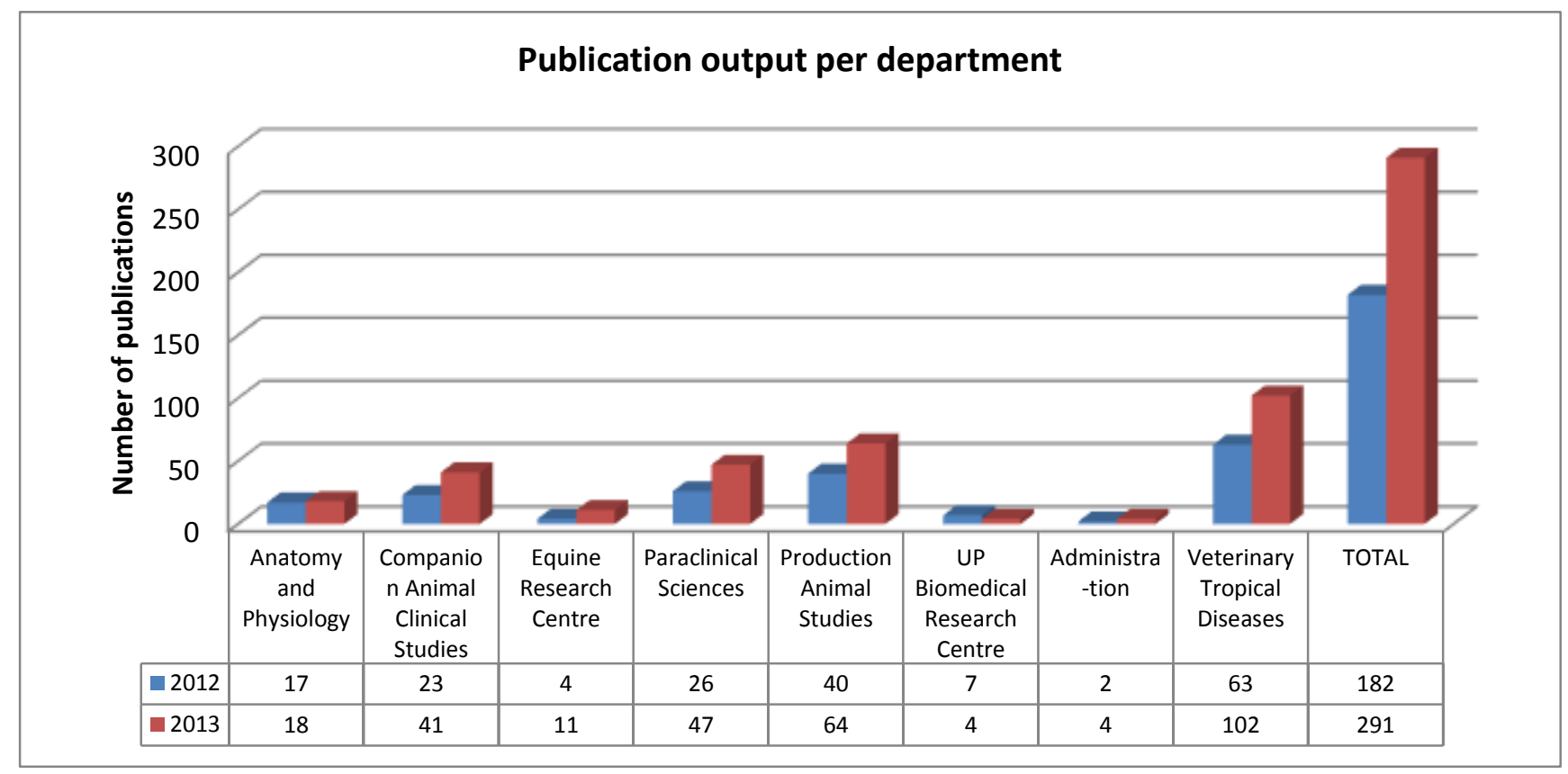

Fig. 1. Publication output per department (comparison between 2012 and 2013) 


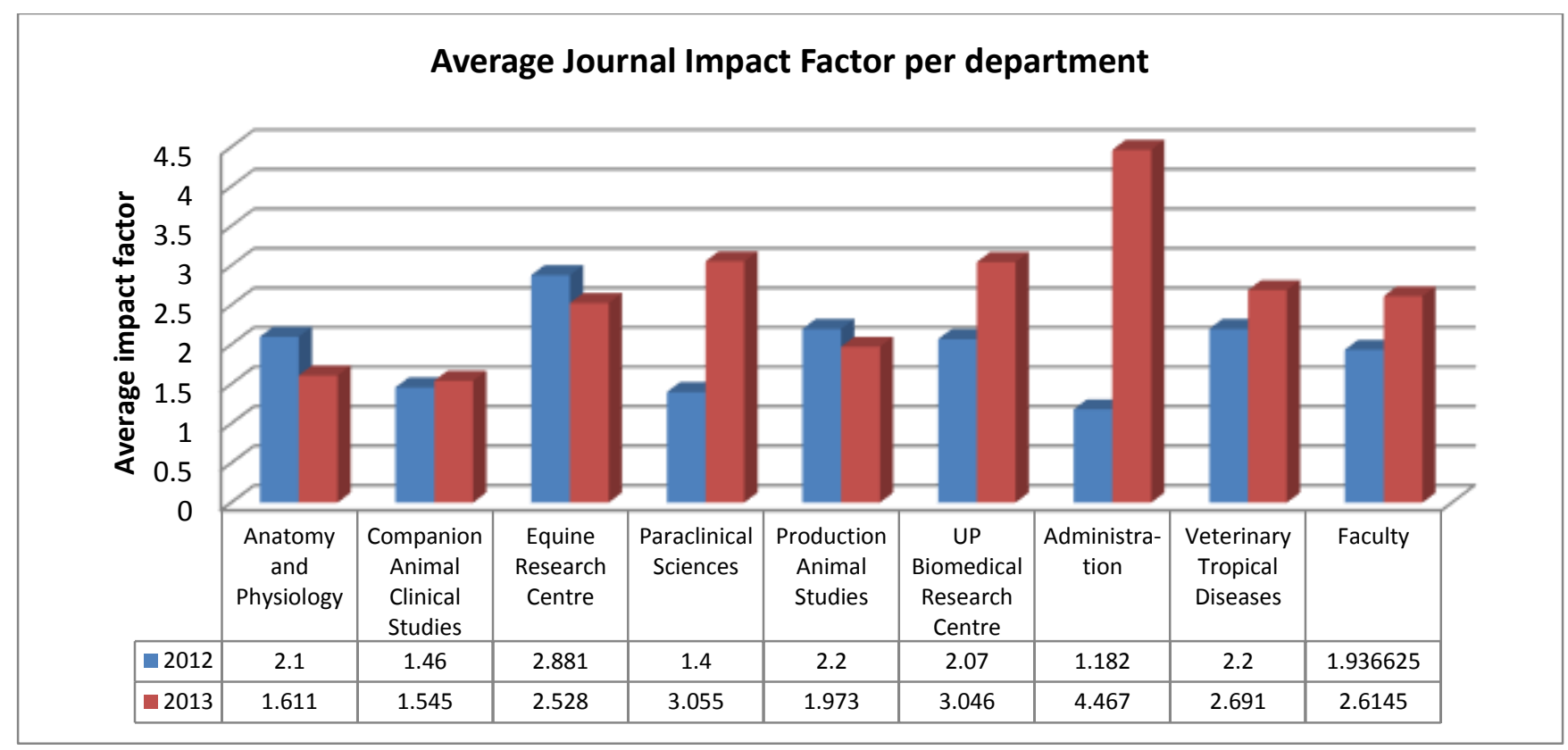

Fig. 2. Average journal impact factor per department (comparison between 2012 and 2013)

Journal titles in which researchers published during 2012 and 2013 were checked for international visibility. All publications were on the Thomson Reuters (ISI) Web of Science indexed journal list or the DoHET lists of accredited journals (thus journals which are included in the South African Government subsidy scheme for higher education institutions). Journal Citation Reports (JSR) of the ISI was used to obtain the impact factors of the journals. During 2012 journals with the highest number of publications were Veterinary Parasitology (9\%), Journal of the South African Veterinary Association (9\%), followed by the Onderstepoort Journal of Veterinary Research (7\%), and in 2013, Journal of the South African Veterinary Association (8\%), Transboundary and Emerging Diseases (4\%) and Plos One (3\%). Both the Journal of the South African Veterinary Association and the Onderstepoort Journal of Veterinary Research are local journals. Their impact factors and international visibility is lower than the other journals', and both are accredited locally. Choosing a journal to publish in only for its international visibility is not always feasible, as many parochial (local) journals provide better coverage of locally important topics, issues and practices (Meneghini, Mugnaini \& Packer, 2006; Ofori-Adjei, Antes, Tharyan, Slade \& Tamber, 2006; Shetty, 2008). In South African more prestige is, however, attached to publication in international journals. 


\section{INFORMATION NEEDS AND INFORMATION BEHAVIOUR OF VETERINARIANS: A REVIEW OF RELATED LITERATURE}

Knowledge of information needs and information behaviour should inform the design of information systems and information services (Hepworth, 2004; Spink, Foster, \& Hepworth, 2007). An information need refers to the recognition that one's knowledge is inadequate to satisfy a specific goal (Case, 2012; Dervin, 1992; Ingwersen \& Järvelin, 2005). According to Wilson (2006, p. 663) information needs are secondary needs arising from a desire to satisfy primary needs (such as physiological needs, affective needs and cognitive needs). These needs are not primarily responsible for information seeking and use, but they can "trigger" information seeking. The needs for research recognition and meeting with institutional and country expectations are such primary needs. When a person becomes aware of a need for information (i.e. a knowledge gap) and addresses it by taking conscious steps or actions to acquire information, information seeking occurs (Wilson, 2000, p. 49). Incorporating the new found information into a persons' current knowledge base, is called information use (Spink \& Cole, 2006). Information behaviour is an umbrella concept for information related activities such as the recognition of information needs, information seeking, avoidance of information and the use of information (Case, 2012; Savolainen, 2007; Wilson, 2000).

Many studies have reported on information needs as well as factors instigating the information needs of students and researchers in a variety of disciplines (Ellis, 1993; Fry \& Talja, 2007; Heïnstrom, 2006; Lonnqvist, 2007; Talja, 2005). Such factors include the research environment, work roles and tasks of researchers, and other motivational factors such as financial rewards. Demographic factors such as age and level of education have also been noted to influence information behaviour (Case, 2012). Instigators of information needs and information seeking and barriers to information seeking are reflected in the well-known models of Wilson $(1999,2006)$, Dervin (1992), Ellis (1993) and Kuhlthau (1991). A model by Leckie, Pettigrew and Sylvain (1996) on the information seeking of professionals acknowledges work roles and tasks, as well as awareness of information needs and sources of information in information seeking behaviour as important in instigating information needs, the use of information sources and information seeking. 
A limited number of studies reporting on the information needs and information behaviour of veterinarians could be traced. These include studies reporting on under-graduate and post-graduate (master's and doctoral) students, studies reporting on academic staff, and studies on veterinary practitioners. Some of the earlier studies on veterinarians indicated a need for the library as main provider of information sources and support (Drake \& Woods, 1978; Raw, 1987; Schmidt, 1991), while more recent studies, such as studies by Biswas and Haque (2008), Haines, Light, O'Malley and Delwiche (2010), Pelzer and Wiese (2005) and Wales (2000) revealed a preference for online information products and services. Nel and Fourie (2010) also found that veterinary professionals in South Africa prefer the internet with its speed and convenience as their primary information resource.

Veterinary researchers prefer electronic information resources for searching and accessing information and library collections (Chikonzo \& Aina, 2001; Pelzer, Wiese \& Leysen, 1998; Prakash, 2013; Shokeen \& Kumar, 2009). Libraries are not their only access point to information (Tennant \& Cataldo, 2002), although library space to work on research is important (Neal, 2009). Some research found that researchers need library support with more complicated topics (Shiri \& Revie, 2003).

In the library and information science literature there are differences in opinion on what can be learned from information behaviour studies. Researchers from different disciplines have different information needs and take different approaches to satisfy these information needs (Gannon-Leary, Bent \& Webb, 2008; Hemminger, Vaughan \& Adams, 2007; Herman, 2001; Schonfeld \& Guthrie, 2007; Sheeja, 2010; Tennant $\&$ Cataldo, 2002). Some authors argue that librarians need to have more knowledge about the subject fields in which their users are involved (Allan, 2010; Brophy, 2008; Schonfeld \& Guthrie, 2007). Gannon-Leary et al. (2008) and Tennant (2005) disagree with this when arguing that research is becoming more multidisciplinary and therefore the needs for information support and literature more diverse. What is especially important is that researchers' information needs are evolving and changing all the time and thus need to be monitored and assessed routinely.

Since reports on veterinary libraries and information services are rather limited; exceptions being - Biswas and Haque (2008), Chikonzo and Aina (2001), Haines et al. (2010), Nel and Fourie (2010), Pelzer et al. (1998), Prakash (2013), Shokeen and 
Kumar (2009), Tennant and Cataldo (2002), we also considered research on services for other disciplines. Examples of changes in library services are new, fast and immediate options of service delivery in the physical library (e.g. self-service circulation), virtual library environments (24/7 communication and access) (Brophy, 2008; Webb et al., 2008), immediate attention being paid to user expectations and needs (Musoke, 2008; Neal, 2009), embedded librarianship in faculty projects and curricula (Corall, 2010; Schumaker, 2011), enhanced communication within the scholarly community (Brown, 2010), increased sharing and collaboration regarding information resources (Mullins, 2012), improved collection development practices (Ross \& Sennyey, 2008), involvement in knowledge creation, increased involvement in preservation and publishing (Case, 2008) as well as in information policies and ethical issues (Neal, 2009). For researchers to benefit from such services they need to be aware of what libraries offer (Neal, 2009). Information specialists need to stay relevant in changing environments. They need to align their roles and functions strategically with the information needs of researchers, develop appropriate information services, embrace opportunities provided by dynamic research environments (Mullins, 2012) and enhance their knowledge and skill sets.

\section{RESEARCH DESIGN}

The empirical component searched answers for the following sub-questions:

- What are the information needs, information seeking behaviour and information use behaviour of veterinary researchers at the Faculty of Veterinary Science, University of Pretoria?

- What information support services and products are currently offered by the Jotello F Soga Library?

- How can the Jotello F Soga Library address the information needs and support the information seeking behaviour and information use behaviour of the researchers at the Faculty of Veterinary Science, University of Pretoria and fill gaps in the library service?

The Faculty of Veterinary Science at the University of Pretoria and the Jotello F. Soga Library were used as a case study with data collection between October 2013 and February 2014. Nel (2015) reports the research design, data collection and findings in more detail. Ethical clearance to conduct the research was obtained from 
the Research Ethics Committee in the Faculty of Engineering, Built Environment and Information Technology (EBIT), University of Pretoria, and all participants gave informed consent for their participation and where applicable, for the focus group interviews to be recorded. Quantitative as well as qualitative data was collected.

\section{Research participants}

Research participants consisted of researchers (including faculty/academic staff, masters' and doctoral students) from the Faculty of Veterinary Science, University of Pretoria at the time of data collection, as well as three information specialists from the Library. The research participants, research methodologies and research methods are reflected in Table 1.

Table 1: Summary of research methodology and research participants for the empirical component

\begin{tabular}{|c|c|c|c|c|c|}
\hline & Questionnaires & Questionnaires & $\begin{array}{l}\text { Focus group } \\
\text { interviews }\end{array}$ & $\begin{array}{l}\text { Focus group } \\
\text { interviews }\end{array}$ & $\begin{array}{l}\text { Citation } \\
\text { analysis }\end{array}$ \\
\hline $\begin{array}{l}\text { Research } \\
\text { method }\end{array}$ & $\begin{array}{l}\text { Quantitative and } \\
\text { qualitative }\end{array}$ & $\begin{array}{l}\text { Quantitative and } \\
\text { qualitative }\end{array}$ & Qualitative & Qualitative & Quantitative \\
\hline Population & $\begin{array}{l}\text { Researchers at the } \\
\text { Faculty of Veterinary } \\
\text { Science, UP }\end{array}$ & $\begin{array}{l}\text { Information } \\
\text { specialists at the } \\
\text { Jotello F Soga } \\
\text { Library, UP }\end{array}$ & $\begin{array}{l}\text { Researchers at } \\
\text { the Faculty of } \\
\text { Veterinary } \\
\text { Science, UP }\end{array}$ & $\begin{array}{l}\text { Information } \\
\text { specialists at } \\
\text { the Jotello F } \\
\text { Soga Library, } \\
\text { UP }\end{array}$ & $\begin{array}{l}\text { Research } \\
\text { output of the } \\
\text { Faculty of } \\
\text { Veterinary } \\
\text { Science, UP }\end{array}$ \\
\hline $\begin{array}{l}\text { Population } \\
\text { size }\end{array}$ & 361 & 3 & 361 & 3 & Not applicable \\
\hline Sample & $\begin{array}{l}\text { All researchers } \\
\text { (faculty and } \\
\text { academic staff, } \\
\text { master's students, } \\
\text { doctoral students) }\end{array}$ & $\begin{array}{l}\text { All information } \\
\text { specialists }\end{array}$ & $\begin{array}{l}\text { Campus-based } \\
\text { researchers } \\
\text { and/or } \\
\text { postgraduate } \\
\text { students }\end{array}$ & $\begin{array}{l}\text { All information } \\
\text { specialists }\end{array}$ & $\begin{array}{l}\text { List of } 2012 \text { and } \\
2013 \text { faculty } \\
\text { publications } \\
\text { obtained from } \\
\text { research office }\end{array}$ \\
\hline $\begin{array}{l}\text { Sampling } \\
\text { technique }\end{array}$ & Not applicable & Not applicable & $\begin{array}{l}\text { Purposive } \\
\text { sampling }\end{array}$ & $\begin{array}{l}\text { Purposive } \\
\text { sampling }\end{array}$ & Not applicable \\
\hline $\begin{array}{l}\text { Number of } \\
\text { participants }\end{array}$ & 119 & 3 & 21 & 3 & Not applicable \\
\hline $\begin{array}{l}\text { Response } \\
\text { rate (\%) }\end{array}$ & $33 \%$ & $100 \%$ & Not applicable & Not applicable & Not applicable \\
\hline
\end{tabular}

\section{Methods of data collection}

A self-administered electronic questionnaire was used to collect data from the researchers on the demographic detail, information needs, information seeking behaviour, information use behaviour, current support by the Library and the current and future role of the information specialist in information support to researchers.

A questionnaire was used to collect data from the information specialists on their own involvement in research, current services provided to researchers and their perceptions on the information needs of researchers as well as their role in 
addressing information needs of researchers. For both groups the questionnaires collected mostly quantitative data.

A personally addressed e-mail, inviting researchers to complete the online questionnaire was sent to all researchers (the population) at the time of data collection. From the 397 questionnaires sent out, 36 were not delivered. Nondeliverability due to wrong or no longer existing e-mail addresses can be a problem when conducting internet surveys (Hoonakker \& Carayon, 2009). The final response rate after four rounds of invitations to participate was 33\% (119/361 respondents). In comparison to similar studies, the response rate of $33 \%$ is acceptable. Some of the studies reviewed for this research reported lower response rates. A study by Al-Suqri (2011) among social science scholars returned 21 responses to 70 e-mailed questionnaires (a 30\% response rate); Korjonen-Close (2005) reported a response rate of only $7.9 \%$ to an internet questionnaire investigating the information needs of clinical researchers and Hart and Kleinveldt (2011) accepted a response rate of 17\% in their study on South African researchers' perspectives on the role of the academic library in research. More than one data collection method is suggested to accommodate low response rates (AI-Suqri, 2011; Leedy \& Ormrod, 2014; Powell \& Connaway, 2004). Participation according to academic ranking was as follows: 42 academic staff; three postdoctoral fellows; 24 doctoral students and 50 masters' students (see also Table 2).

The responses to the questionnaire were supplemented with five focus group interviews involving 21 researchers (five faculty/academic staff, 13 masters and three doctoral students). The population of information specialists consisted of the three information specialists who are designated to support the researchers.

Focus group interviews with the researchers and the information specialists were used to collect additional qualitative data. All focus group interviews were conducted by the first author of this paper. One of the information specialists of this library assisted in taking notes in the focus group interviews with researchers. Participants in all groups were asked to elaborate on questions asked in the questionnaire. Discussions focused on the role of the Library and information specialists in addressing the information needs of researchers, skills of the information specialists to address the needs of researchers, and shortcomings, successes and the future of 
the Library. These issues were discussed in focus group interviews with researchers as well as with information specialists to obtain data from both perspectives.

The groups consisted of 3 to 6 participants per group; the group size was influenced by problems with the availability of participants.

\section{DATA ANALYSIS AND FINDINGS}

Nel (2015) reports the data analysis and findings in more detail. Descriptive statistics were used for the analysis of quantitative data and thematic analysis for the qualitative data. The reliability and validity of findings were ensured by using more than one instrument for data collection (reliability), by using multiple sources of evidence (validity) and by developing the instruments for data collection to build on findings from the literature analysis (face and content validity). The use of different instruments for data collection, different sources of information and different approaches in the analysis of data, also allowed for the triangulation of findings (Leedy \& Ormrod, 2014).

The next two sub-sections will report findings from the data collected from the researchers and information specialists respectively. For each the quantitative data, and then the qualitative data are reported. The findings on perceptions on the role of information specialists (quantitative and qualitative data) are dealt with under a separate heading to compare input from the researchers and information specialists.

\section{Data collected from the researchers}

A questionnaire was used to collect data on demographic detail, as well as the information needs, information seeking and information use of the researchers. Demographic data is presented in Table 2. 
Table 2: Faculty and research involvement of respondents

\begin{tabular}{|c|c|c|c|}
\hline \multirow{2}{*}{\multicolumn{2}{|c|}{$\begin{array}{l}\text { Faculty involvement } \\
(n=119)\end{array}$}} & \multicolumn{2}{|l|}{ Research involvement: } \\
\hline & & No research involvement & 5 \\
\hline Professor & 7 & Yes, for masters' degree purposes & 67 \\
\hline Associate professor & 4 & Yes, for doctoral degree purposes & 37 \\
\hline Senior lecturer & 17 & Yes, for post-doctoral degree purposes & 6 \\
\hline Lecturer & 5 & As contract researcher & 3 \\
\hline Junior lector & 7 & Other research projects & 11 \\
\hline Assistant lector & 0 & or of postgraduate students: & \\
\hline Research staff & 1 & Not a supervisor & 93 \\
\hline Postdoctoral & 3 & Yes, for students doing masters' mini-dissertation & 12 \\
\hline Doctoral student & 24 & Yes, for students doing research masters' dissertation & 17 \\
\hline Master's student & 50 & Yes, for doctoral students & 9 \\
\hline Other (specify) & 1 & Supervisor of other research projects & 2 \\
\hline Total & 119 & & \\
\hline
\end{tabular}

Table 3 gives a summary on the findings on the information needs, information seeking and information use of researchers. Each is then briefly discussed in more detail.

Table 3: Summary of some findings on information needs, information seeking behaviour and information use behaviour of researchers

\begin{tabular}{|c|c|}
\hline Information needs & $\begin{array}{ll}- & \text { Motivated by the research environment (context) } \\
- & \text { Awareness of information resources } \\
- & \text { Awareness of services of the information specialists }\end{array}$ \\
\hline $\begin{array}{l}\text { Information seeking } \\
\text { behaviour }\end{array}$ & $\begin{array}{ll}\text { - } & \text { Significant time is spent on information seeking and searching online } \\
\text { databases }\end{array}$ \\
\hline Information use behaviour & $\begin{array}{ll}- & \text { Do not often use the physical library } \\
\text { - } & \text { Do not attend scheduled library training sessions } \\
\text { - } & \text { Prefer to use online information resources and databases } \\
\text { - } & \text { Prefer face-to-face contact with peers as first choice method for keeping } \\
& \text { up to date with new developments }\end{array}$ \\
\hline
\end{tabular}

\section{Information needs of researchers}

The information needs of veterinary science researchers are motivated by the research environment, which puts pressure on researchers for increased high-quality and quantity research output. This is clear from the citation analysis of the 2012 and 
2013 research output of the Faculty, indicating an increase in research output in high-quality journals, as well as the number of publications.

The impact of demands of the research environment on the information behaviour of researchers was also confirmed, when respondents indicated the following as criteria used when selecting an appropriate publication outlet for their research: journal reputation (including the impact factor, credibility and prestige of the journal) (97/119; $82 \%)$; accredited journal (62/119; 52\%); focus and orientation of the journal (56/119; $47 \%$ ); likelihood of manuscript to be accepted (56/119; 47\%); recommendation by peers (49/119; 41\%); past experience with the journal (39/119; 33\%); journal visibility $(31 / 119 ; 26 \%)$; timeline from submission to publication $(24 / 119 ; 20 \%)$; cost $(23 / 119$; $19 \%)$; open access (12/119; $11 \%)$; intellectual property or copyright issues $(7 / 119$; $6 \%)$ and recommended by supervisor (5/119; 4\%).

Apart from the context, awareness of information resources as well as awareness and availability of the services provided by the information specialists may also "trigger" information needs of researchers. This is confirmed by work by Leckie, Pettigrew and Sylvain (1996).

The qualitative data collected from the open ended questions in the questionnaire as well as from the focus group interviews with the researchers revealed that veterinary researchers need access to all needed information and information resources. This confirms work by Case (2008), Munde and Marks (2009), Musoke (2008) and Schonfeld and Guthrie (2007) indicating that researchers rank access to information resources very highly. Similar to findings from these studies, nearly all participants from the focus group interviews indicated a preference for online sources, allowing easy, effortless and limitless access.

Some responses (verbatim) from the focus group interviews were:

"[The library] helps with article requests, help with database use, and providing online access to the multitude of journals we all need which is hugely appreciated!!"

"As I seldom visit campus, I rely on the use of electronic journal articles which are excellent." 
"I think the library services are valued but used little by many academic staff due to the ease of direct, electronic sources."

Several respondents also explicitly raised a need for more personalised and proactive service from their information specialists. Some responses from the focus group interviews included:

"Maybe they can be more pro-active and forward articles that appear interesting or valuable to us as we cannot screen everything..."

"I want the library to provide me with lists of the journals in which UP staff publish; their research topic and with current impact factors; e-mail notification of new publications (including contents of journals) in my study field to me..."

A concern, however, is that researchers are unaware of the support of the information specialists who are available to assist them. The following remarks were noted by two respondents in one of the focus group interviews:

"I don't really know how to use an information specialist and how much and for what I can use one."

Another researcher in response:

"I do not even know if I am allowed to contact her ..."

In another focus group interview, one respondent remarked the following:

"I would like my librarian to assist me with a subject search. Just not sure I am allowed to ask them ..."

Munde and Marks (2009, p. 111) argue that "faculty access to digital resources their availability, ease and speed of retrieval, and ubiquity of delivery - has very likely contributed to increased faculty productivity over time." In order to play a more relevant role in Faculty research, the Library needs to re-access and align its collection building practices according to the information needs of researchers and invest even more in easily accessible, easy to use electronic information resources. Information specialists need to focus on raising awareness of services and not only on library products. They should also focus on their skills and how they can 
contribute to institutional research goals and the research success of the departments they support.

\section{Information seeking behaviour of researchers}

Participants were asked to indicate the percentage time devoted to information seeking for research. Most respondents (85/119; 71\%) indicated that they spend less than $50 \%$ of their time on information seeking, while $34 / 119(29 \%)$ respondents indicated that they spend more than $50 \%$ of their time on information seeking. Data also indicated that $116 / 119(97 \%)$ of the respondents are responsible for their own information seeking, while 59/119 (50\%) indicated they sometimes involve the information specialists to assist them with information seeking and 22/119 (18\%) indicated they never involve the information specialist.

The methods used most often as well as least often by researchers when seeking information are presented in Table 4.

Table 4: Summary of methods used by researchers to find information for research

\begin{tabular}{|ll|}
\hline Information seeking methods used most often by & $\begin{array}{l}\text { Information seeking methods used least often by } \\
\text { researchers }\end{array}$ \\
\hline Electronic reference databases (e.g. CAB Abstracts) & Online table of contents of a journal $(5 \%)$ \\
$(42 \%)$ & References or footnotes $(3 \%)$ \\
Full-text electronic databases (e.g. ScienceDirect) $(41 \%)$ & Hard-copy directories or bibliographies $(1 \%)$ \\
Google or Google Scholar (38\%) & \\
\hline
\end{tabular}

Respondents were asked to indicate the level of confidence that their information needs were being satisfied on a scale from one to ten (where one was "very confident" and ten was "not confident at all"). Table 5 presents the responses to this question.

Table 5: Level of confidence that information needs are being satisfied

\begin{tabular}{|ccccccccccccc|}
\hline $\begin{array}{l}\text { Level of } \\
\text { confidence: }\end{array} \quad \begin{array}{l}\text { Very } \\
\text { confident }\end{array}$ & 1 & 2 & 3 & 4 & 5 & 6 & 7 & 8 & 9 & 10 & $\begin{array}{l}\text { Not confident } \\
\text { at all }\end{array}$ \\
\hline $\begin{array}{c}\text { Number of } \\
\text { responses }(n=119)\end{array}$ & 6 & 35 & 36 & 20 & 7 & 2 & 5 & 6 & 2 & 0 \\
$\%$ & $5 \%$ & $29 \%$ & $30 \%$ & $17 \%$ & $6 \%$ & $2 \%$ & $4 \%$ & $5 \%$ & $2 \%$ & $0 \%$ \\
\hline
\end{tabular}


Information use behaviour of researchers

Respondents' use and reasons for using the library during the 12 months preceding data collection is indicated in Figure 3. The findings show that a remarkable number of respondents $(17 / 119 ; 14 \%)$ had never visited the Library in person, 29/119 (24\%) had never discussed their information needs with information specialists, 48/119 (40\%) had never received one-to-one training from an information specialist and $68 / 119(57 \%)$ had never attended a scheduled library training session. A large number $(62 / 119 ; 52 \%)$ of respondents, however, indicated that they visited the Jotello F Soga Library in person between one and five times during the previous year, while $70 / 119$ (59\%) discussed their information needs with an information specialist between one and five times during the previous year.

The findings from the literature indicate that in earlier studies the library used to play a much more prominent role in addressing the information needs of veterinary science researchers (Chikonzo \& Aina, 2001; Nweke, 1995). More recent studies among veterinary science researchers however found that because of the increased use of online sources, researchers tend to visit the physical library less often (Prakash, 2013; Shokeen \& Kuman, 2009). This also contribute to the need for the Library to re-assess its' value and role as an important support service at the Faculty.

As one-to-one training on online library products and collections are regularly presented to newly enrolled postgraduate students, a large number of respondents $(67 / 119 ; 56 \%)$ indicated that they received training between one and five times. One respondent indicated that he or she received one-to-one training between 21 and 30 times. This was confirmed with the information specialist as to be training in "RefWorks".

Scheduled library training sessions are presented during lunch hours. Most respondents $(47 / 119 ; 39 \%)$ attended between one and five sessions, 2/119 (2\%) attended between six and 10 sessions. It was confirmed that one senior lecturer attended every scheduled library training session during the previous year. 


\begin{tabular}{|c|c|c|c|c|c|c|}
\hline \multicolumn{7}{|c|}{ Use of the library ( $n=119)$} \\
\hline \\
\hline 60 & & & & & & \\
\hline 50 & & & & & & \\
\hline 30 & & & & & & \\
\hline 20 & & & & & & \\
\hline 10 & & & & & $\overline{\mathbf{L}}$ & $\pi$ \\
\hline & Never & $1-5$ times & $\begin{array}{l}6-10 \\
\text { times }\end{array}$ & $\begin{array}{c}11-20 \\
\text { times }\end{array}$ & $\begin{array}{c}21-30 \\
\text { times }\end{array}$ & $\begin{array}{c}\text { More than } \\
30 \text { times }\end{array}$ \\
\hline $\begin{array}{l}\text { Visit the Jotello F Soga library in } \\
\text { person }\end{array}$ & 17 & 62 & 24 & 4 & 7 & 5 \\
\hline $\begin{array}{l}\text { Discussed information needs with } \\
\text { information specialist }\end{array}$ & 29 & 70 & 14 & 2 & 2 & 2 \\
\hline Received one-to-one training & 48 & 67 & 1 & 2 & 1 & 0 \\
\hline $\begin{array}{l}\text { Attended a scheduled library training } \\
\text { session }\end{array}$ & 68 & 47 & 2 & 0 & 1 & 1 \\
\hline
\end{tabular}

Fig. 3. Average use of the physical library during the 12 months preceding data collection

Findings on information resources used for research are summarised in Table 6. These findings are similar to findings by Hemminger et al. (2007) who found that researchers prefer electronic journals and scientific databases for searching and accessing scholarly information.

Table 6: Summary of information sources used by researchers

\begin{tabular}{|ll|}
\hline $\begin{array}{l}\text { Information sources used most often by } \\
\text { researchers }\end{array}$ & $\begin{array}{l}\text { Information sources used least often by } \\
\text { researchers }\end{array}$ \\
\hline Journal articles (electronic) (55\%) & Social networks $(5 \%)$ \\
Scientific databases (41\%) & Conference attendance (1\%) \\
Internet search tools (39\%) & Departmental colleagues (1\%) \\
\hline
\end{tabular}

When respondents were asked to indicate all the methods they prefer to keep up-todate with new developments in their field, most indicated personal contact with peers as preference. Methods to keep up-to-date were indicated as follows: conferences, meetings and workshops (87/119; 73\%); personal communication with colleagues (72/119; $61 \%)$; contents pages of electronic journals $(61 / 119 ; 52 \%)$; online journal contents pages alerts $(39 / 119 ; 33 \%)$; discussions on social networks $(38 / 119 ; 32 \%)$; contents pages of new e-books (28/119; 24\%); RSS feeds (14/119; $12 \%)$; contents 
pages of new books in the library (12/119; 10\%) and contents pages of printed journals in the library $(9 / 119 ; 8 \%)$.

Several other authors (including Korjonen-Close, 2005; Neal, 2009; Pantry \& Griffiths, 2009) agree that technological developments enhance access to digital information and collections, resulting in a decrease in visits to the physical library building for information access. Nevertheless, Webb et al. (2008, p. 134) found that researchers still "value the scholarly atmosphere of a research library". This has resulted recently in less library space being taken up by collections, while some libraries have redesigned their floor plans to provide study areas and public spaces. Neal (2009) addresses this issue and suggests that library management need to think more flexibly and adaptably about library space for research. The need for library space was raised by several participants in the focus group interviews (see Figure 5).

\section{Data collected from the information specialists}

A questionnaire was used to collect data from the information specialists on the departments and research centres they served, services and support provided to researchers, whether they are conducting research projects, their own involvement in research projects and their publication record.

The departments and research centres are divided between the information specialists and are presented in Table 7. The information specialists do not have subject expertise relevant to the units they serve.

Table 7: Distribution of faculty departments among information specialists

\begin{tabular}{|l|l|l|}
\hline Information specialist 1 & Information specialist 2 & Information specialist $\mathbf{3}$ \\
\hline $\begin{array}{l}\text { Companion Animal Clinical Studies } \\
\text { Anatomy and Physiology Equine Research }\end{array}$ & Veterinary Tropical Diseases & Paraclinical Studies, \\
Centre & UP Biomedical Research Centre & Centre for Wildlife Studies \\
\hline
\end{tabular}

The information specialists were not conducting their own research projects or involved in their own or any research projects of others. Apart from four scholarly articles in accredited journals (two as single authors and two in collaboration with colleagues), their publications were limited to the library's in-house newsletter, 
Infomania (http://www.library.up.ac.za/vet/infomania.htm), contributions to conference proceedings, and to their own blogs for marketing new products and information resources to researchers. Although they thus have some experience in publication, their experience of the academic publishing and scholarly communication environment is very different from the highly competitive and demanding environment of scholarly publication in which researchers operate. This is similar to findings by Darch and De Jager (2012).

During the focus group interview of 75 minutes, the information specialists were asked about their role in supporting the information needs of researchers. The services they provide to researchers are fairly typical of library services noted in the subject literature (including among others Corall, 2010; Hart \& Kleinveldt, 2011; Musoke, 2008; Webb et al., 2007). These are shown in Table 8.

Table 8: Information support services provided to researchers

\begin{tabular}{|lll|}
\hline $\begin{array}{l}\text { Information searching } \\
\text { (discovery) }\end{array}$ & - & Doing literature searches \\
\hline Information use (resources) & - & Collection development and management \\
& - Development and management of digital and institutional \\
& - Creation of subject portals and web products \\
& - Document delivery \\
\hline $\begin{array}{l}\text { Information regarding } \\
\text { research and methodology }\end{array}$ & - Advising on research publication \\
& - Compising on research methodology \\
& - Providing advice on copyright, plagiarism and referencing \\
\hline Other & - Providing support and advice on reference management tools \\
\hline
\end{tabular}

\section{Findings on the importance and role of the information specialists}

The researchers' and information specialists' opinions on the importance of the information specialists were assessed by the questionnaires to both groups; they were asked to rate the importance of the information specialists on a ten point Likert scale. Responses from 118 researchers and all three information specialists were recorded. The findings are presented in Table 9. A large number of researchers $(79 / 118 ; 67 \%)$ as well as all three information specialists viewed information specialists as very important. The 10/118 (8.5\%) that does not consider information specialists to be important (although a low percentage), however, presents a challenge for the Library. 
Table 9: Views of researchers and information specialists on the importance of the information specialists

\begin{tabular}{|r|cccccccccccc|}
\hline Level of importance: & $\begin{array}{c}\text { Very } \\
\text { important }\end{array}$ & 1 & 2 & 3 & 4 & 5 & 6 & 7 & 8 & 9 & 10 & Not \\
& & & & & & & & & & \\
important
\end{tabular}

Data on the role of the information specialists were collected during the focus group interviews with both groups. Participants were asked to name the three most important roles of the information specialists. The intention was to identify gaps between expectations and the services offered as well as opportunities for the information specialists to expand and strengthen their roles according to the researchers' expectations. The question also helped to reveal the knowledge and skills information specialists require as well as the challenges they face. Responses to the question were normalised and average percentages worked out in order to compare responses from the two groups. The three most important as well as three least important roles are compared and presented in Figure 4.

As shown in Figure 4, there is considerable dissimilarity between the perceptions of researchers and the perceptions of information specialists. Although the opinion of only three information specialists may be a very limited base from which to make significant conclusions, it indicates the need for academic librarians to compare their perceptions to those of their users in order to identify gaps in their services.

Researchers view the role of the information specialists as more resource and collection based (traditional library functions), while information specialists view their role as more involved in the discipline (subject) and research domain of the Faculty they support. 


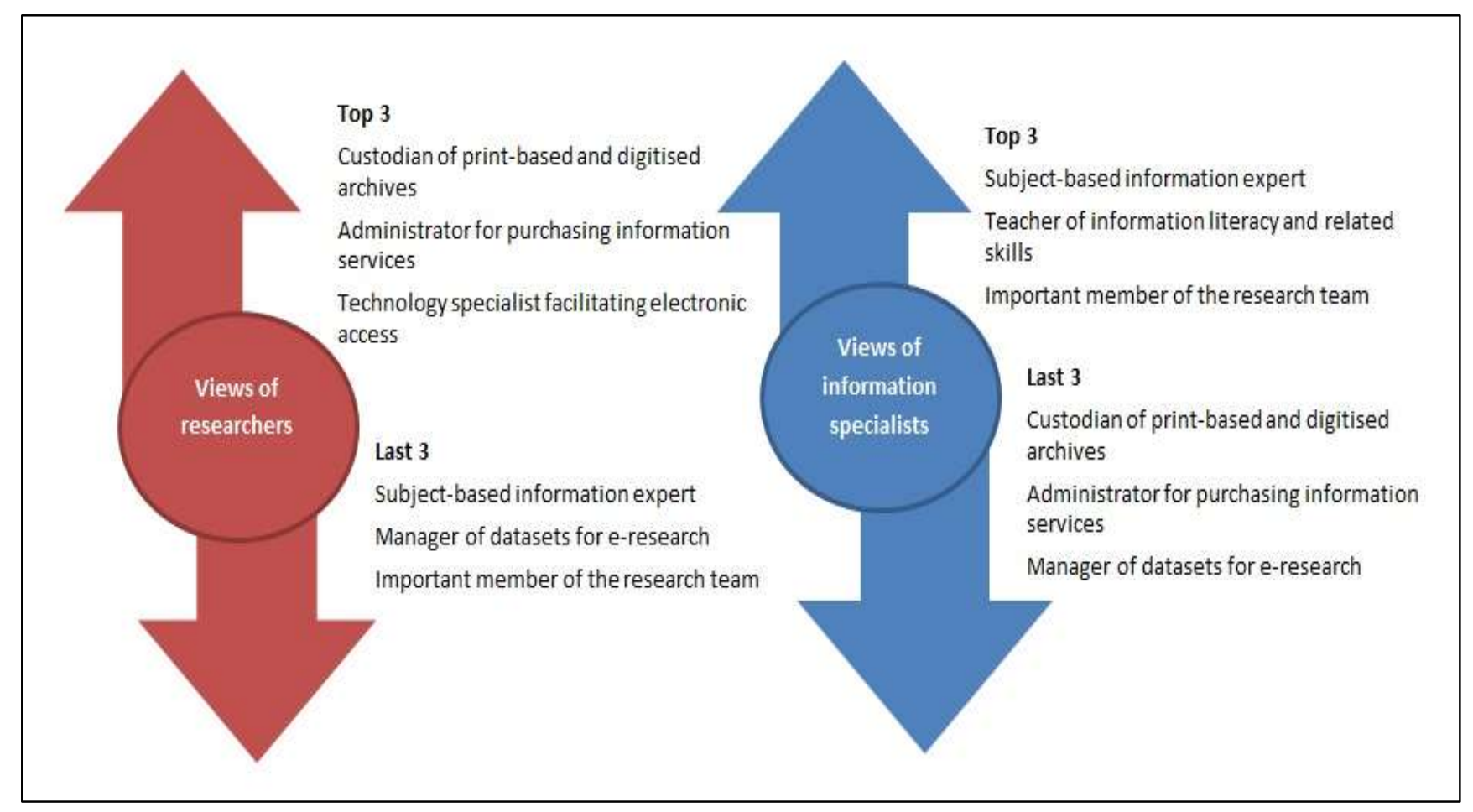

Fig. 4. Summary of the different views on the roles of the information specialists

Researchers were asked if they thought the information specialists of the Jotello $\mathrm{F}$ Soga Library were adequately skilled to support their information needs. A large number $(115 / 119 ; 97 \%)$ indicated that they felt the information specialists were adequately skilled, while only (4/119; 3\%) answered negatively to this question. Although this is a positive outcome, it is important to note that libraries cannot simply rely on this, since the rest of the results pointed to the need for re-assessment of skills development, and continuing professional development.

Supplementary to this, both groups were also asked in the focus group interviews to discuss the skills of the information specialists they view as important. Responses were noted and grouped into themes. Considerable gaps between researchers' opinions regarding the skills of information specialists and of information specialists' own opinions regarding their needed skills exist. This also confirms the need for aligning skills development initiatives of information specialists with researchers' information needs.

Most researchers mentioned skills related to the finding of information as most important. Phrases raised include among others the following: 
"Information specialists need skills for finding articles, books, book chapters and so on when we did not have them..."

"...being able to answer my questions for information and help resolve my problems with the methods of finding information..."

All information specialists, on the other hand, indicated subject expertise, presentation and teaching skills and team-working as important.

\section{Needs of researchers and how these needs are addressed by the library}

Other issues addressed by open-ended questions in the questionnaires, as well as discussions in the focus group interviews with researchers and information specialists respectively, were on what researchers need from the Library, what researchers think the Library does well, what information specialists think the needs of researchers are and what needs information specialists cannot address.

Responses were analysed and grouped according to themes. A summary of the findings is presented in Figure 5.

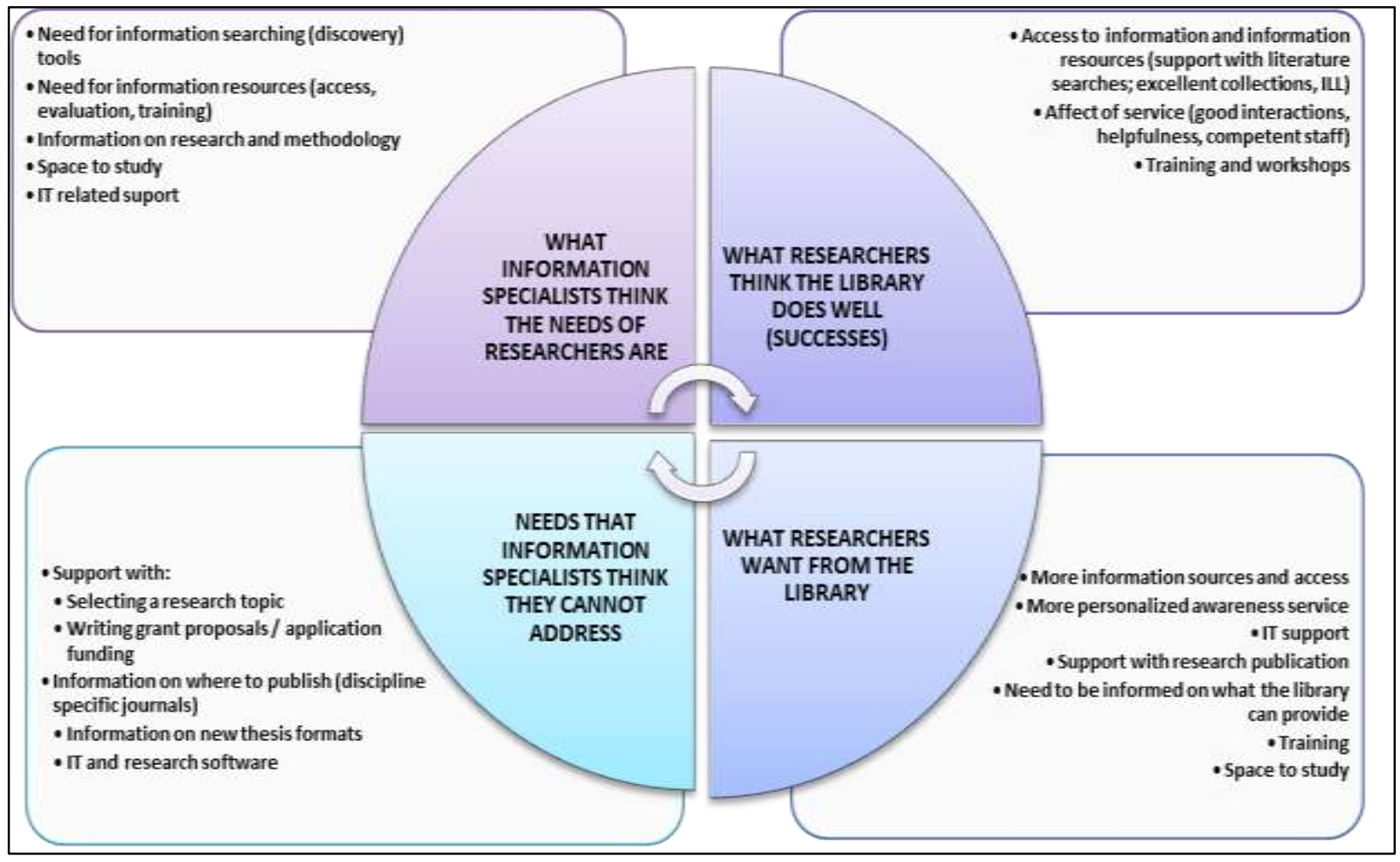

Fig. 5. Overview on the information needs of researchers 


\section{CONCLUSION}

The aim of this study was to determine the information needs, information seeking behaviour and information use behaviour of researchers at the Faculty of Veterinary Science, University of Pretoria and how these needs are being met by the information support delivered by the Jotello F Soga Library.

The study pointed out that national and institutional strategies regarding research output impact on the information needs of researchers. Context is thus confirmed as having an important impact on information needs and information behaviour. The combination of research methods as well as research participants showed the value of using more than one method, and also how much researchers' expectations for support from an academic library might differ from perceptions of the information specialists. Overall findings can be used to portray what is offered in terms of library services, what are expected, and how services need to be adapted - including the role of the information specialists.

The study found that challenges posed by the research environment and institutional goals affect the information needs of researchers. Information support initiatives from the Library thus need to be aligned with institutional goals and researchers' expectations and focused on challenges in the dynamic research environment. This aligns with findings from several other authors, including Brophy (2008), Darch and de Jager (2012), Fourie (2004) and Webb et al. (2007). Since demands and needs can change these should constantly be monitored.

A library should also address the expressed needs of researchers, such as the need for an area in the library exclusively for researchers and more personalised service to Faculty departments. These needs need to be aligned with trends in the global research library environment.

The importance of the library collections (especially the online collections) for researchers was confirmed. Mullins (2012) emphasises the important role of the academic library in collection development, when saying that "the unique role that university research libraries have traditionally had that separates them from other types of libraries is the expectation that a university research library will be committed to growing and stewarding ever larger, comprehensive collections". Given 
that researchers rank access to information resources high, this study recommends that collection development and management must be viewed as priority for the library. Bearing in mind that researchers prefer online information resources, the library needs to invest even more in electronic resources, which are easy to access and use. It is further suggested that in order to include access to information not owned, the library must establish more partnerships and get involved in collaboration initiatives.

Given that the Jotello F Soga Library is the only academic library supporting a veterinary science faculty in South Africa, it is recommended that this library benchmarks its collection with other international veterinary faculties and schools, for example in the USA and Europe. This will enable the library to determine the quality of the collection, identify best practices and evaluate whether the collection is in line with institutional strategies and goals regarding research output.

Information specialists can play an important role and fulfil various functions in dynamic research environments (Mullins, 2012; Neal, 2009; Webb et al., 2007), yet, this study found that researchers are often unaware of the skills and expertise of information specialists. Efforts to raise awareness therefore need to include not only the marketing of library products (e.g. databases), but also the expertise of the information specialists in information seeking (e.g. systematic reviews), information organising (e.g. research data management) and skills to enable access to information (e.g. non-print materials, grey literature, special collections, archives) and preservation. By getting involved in their own research, information specialists will further be able to not only demonstrate more advanced research skills, but will also be able to engage with researchers on a higher level.

Although this paper is presented as a case study, it cannot be viewed in isolation, as it has relevance for other academic libraries. Although the literature on information services to veterinary researchers is limited, findings of this study correspond with several other research findings on information services to researchers from a variety of disciplines. Recommendations may therefore be applicable to veterinary libraries as well as other libraries supporting the needs of faculty and academic staff and researchers, including postgraduate students involved in research. 


\section{REFERENCES}

Allan, B. (2010). Supporting research students. London: Facet Publishing.

Al-Suqri, M. N. (2011). Information-seeking behavior of social science scholars in developing countries: A proposed model. The International Information and Library Review, 43(1), 1-14. Retrieved from http://www.tandfonline.com/doi/abs/10.1080/10572317.2011.10762875

Biswas, B. C., \& Haque, M. E. (2008). Information use pattern of researchers in veterinary science and animal husbandry: A citation study. SRELS Journal of Information Management, 45(3), 355-363.

Brophy, P. (2008). Telling the story: Qualitative approaches to measuring the performance of emerging library services. Performance Measurement and Metrics, 9(1), 7-17. Retrieved from http://www.emeraldinsight.com/doi/full/10.1108/14678040810869387

Brown, C. (2010). Communication in the sciences. Annual Review of Information Science and Technology, 44(1), 285-316. Retrieved from http://onlinelibrary.wiley.com/doi/10.1002/aris.2010.1440440114/full

Case, D. O. (2012). Looking for Information: A survey of research on information seeking, needs and behaviour (3rd ed.). London: Emerald Group.

Case, M. M. (2008). Partners in knowledge creation: An expanded role for research libraries in the digital future. Journal of Library Administration, 48(2), 141-156. Retrieved from http://www.tandfonline.com/doi/abs/10.1080/01930820802231336

Chikonzo, A. C., \& Aina, L. (2001). The information environment of veterinary researchers at the University of Zimbabwe. The International Information and Library Review, 33(1), 97-111. Retrieved from http://www.tandfonline.com/doi/abs/10.1080/10572317.2001.10762541 
Corrall, S. (2010). Educating the academic librarian as a blended professional: A review and case study. Library Management, 31(8/9), 567-593. Retrieved from http://www.emeraldinsight.com/doi/full/10.1108/01435121011093360

Courtright, C. (2007). Context in information behavior research. Annual Review of Information Science and Technology, 41(1), 273-306. Retrieved from http://onlinelibrary.wiley.com/doi/10.1002/aris.2007.1440410113/full

Darch, C., \& de Jager, K. (2012). 'Making a difference in the research community': South Africa's library academy experience and the researcher-librarian relationship. The Journal of Academic Librarianship, 38(3), 145-152. Retrieved from http://www.sciencedirect.com/science/article/pii/S0099133312000602

Dervin, B. (1992). From the mind's eye of the user: The sense-making qualitativequantitative methodology. In J. D. Glazier \& R. R. Powell (Eds.). Qualitative research in information management. (pp. 61-84). Englewood, CO: Libraries Unlimited.

Diab, R. D., Gevers, W., \& Academy of Science of South Africa. (2009). The state of science in South Africa. Pretoria: Academy of Science of South Africa.

Drake, M. A., \& Woods, L. A. (1978). An information service for practicing veterinarians. Bulletin of the Medical Library Association, 66(4), 437-440.

Ellis, D. (1993). Modeling the information-seeking patterns of academic researchers: A grounded theory approach. The Library Quarterly, 63(4), 469- 486. Retrieved from http://www.jstor.org/stable/4308867?seq=1\#page_scan_tab_contents

Fourie, I. (2004). Librarians and the claiming of new roles: How can we try to make a difference? Aslib Proceedings, 56(1), 62-74. Retrieved from http://www.emeraldinsight.com/doi/full/10.1108/00012530410516877

Fry, J., \& Talja, S. (2007). The intellectual and social organization of academic fields and the shaping of digital resources. Journal of Information Science, 33(2), 115133. Retrieved from http://jis.sagepub.com/content/33/2/115.short 
Gannon-Leary, P., Bent, M., \& Webb, J. (2007). Researchers and their information needs: A literature review. New Review of Academic Librarianship, 13(1/2), 5169. Retrieved from http://www.tandfonline.com/doi/abs/10.1080/13614530701868686

Habib, A., \& Morrow, S. (2006). Research, research productivity and the state in South Africa. Transformation: Critical Perspectives on Southern Africa, 62(1), 929.

Haines, L. L., Light, J., O'Malley, D., \& Delwiche, F. A. (2010). Information-seeking behavior of basic science researchers: Implications for library services. Journal of the Medical Library Association, 98(1), 73-81. doi:10.3163/15365050.98.1.019.

Hart, G. \& Kleinveldt, L. (2011). The role of an academic library in research: researchers' perspectives at a South African University of Technology. South African Journal of Libraries and Information Science, 77(1), 37-50. Retrieved from http://dx.doi.org/10.7553/77-1-65

Heinström, J. (2006). Broad exploration or precise specificity: Two basic information seeking patterns among students. Journal of the American Society for Information Science and Technology, 57(11), 1440-1450. Retrieved from http://onlinelibrary.wiley.com/doi/10.1002/asi.20432/abstract

Hemminger, B. M., Lu, D., Vaughan, K., \& Adams, S. J. (2007). Information seeking behavior of academic scientists. Journal of the American Society for Information Science and Technology, 58(14), 2205-2225. Retrieved from http://onlinelibrary.wiley.com/doi/10.1002/asi.20686/full

Hepworth, M. (2004). A framework for understanding user requirements for an information service: Defining the needs of informal carers. Journal of the American Society for Information Science and Technology, 55(8), 695-708. Retrieved from http://onlinelibrary.wiley.com/doi/10.1002/asi.20015/abstract

Herman, E. (2001). End-users in academia: Meeting the information needs of university researchers in an electronic age: Part 2 innovative information- 
accessing opportunities and the researcher: User acceptance of IT-based information resources in academia. Aslib Proceedings, 53(10), 431-457. Retrieved from http://dx.doi.org/10.1108/EUM0000000007072

Hoonakker, P., \& Carayon, P. (2009). Questionnaire survey nonresponse: A comparison of postal mail and internet surveys. International.Journal of HumanComputer Interaction, 25(5), 348-373. Retrieved from http://www.tandfonline.com/doi/abs/10.1080/10447310902864951

Ingwersen, P., \& Järvelin, K. (2005). The turn: Integration of information seeking and retrieval in context. Dordrecht: Springer.

Jeenah, M., \& Pouris, A. (2008). South African research in the context of Africa and globally: Science policy. South African Journal of Science, 104(9/10), 351-354. Retrieved from http://www.scielo.org.za/scielo.php?pid=S003823532008000500008\&script=sci_arttext

Kahn, M. (2011). A bibliometric analysis of South Africa's scientific outputs: Some trends and implications. South African Journal of Science, 107(1/2), 1-6. Retrieved from http://dx.doi.org/10.4102/sajs.v107i1/2.406.

Korjonen-Close, H. (2005). The information needs and behaviour of clinical researchers: A user-needs analysis. Health Information and Libraries Journal, 22(2), 96-106. Retrieved from http://onlinelibrary.wiley.com/doi/10.1111/j.14711842.2005.00562.x/abstract

Kuhlthau, C. C. (1991). Inside the search process: Information seeking from the user's perspective. Journal of the American Society of Information Science, 42(5), 361-371. Retrieved from http://onlinelibrary.wiley.com/doi/10.1002/(SICl)10974571(199106)42:5\%3C361::AID-ASI6\%3E3.0.CO;2-\%23/abstract

Leckie, G. J., Pettigrew, K. E. \& Sylvain, C. (1996). Modelling the information seeking of professionals: A general model derived from research on engineers, health care professionals and lawyers. Library Quarterly, 66(2), 161-193. Retrieved from http://www.jstor.org/stable/4309109 
Leedy, P. D., \& Ormrod, J. E. (2014). Practical research: Planning and design (10th, Pearson new international ed.). Harlow, Essex: Pearson Education.

Lonnqvist, H. (2007). The research processes of humanities scholars. Advances in Library Administration and Organization, 25, 175-201. Retrieved from http://www.emeraldinsight.com/doi/abs/10.1016/S0732-0671(07)25009-6

Meneghini, R., Mugnaini, R., \& Packer, A. L. (2006). International versus national oriented Brazilian scientific journals. A scientometric analysis based on SciELO and JCR-ISI databases. Scientometrics, 69(3), 529-538.

Munde, G., \& Marks, K. (2009). Surviving the future: Academic libraries, quality and assessment. Oxford: Chandos.

Mullins, J. L. (2012). The changing definition and role of collections and services in the university research library. Indiana Libraries, 31(1), 18-24.

Musoke, M. G. (2008). Strategies for addressing the university library users' changing needs and practices in Sub-Saharan Africa. The Journal of Academic Librarianship, 34(6), 532-538. Retrieved from http://www.sciencedirect.com/science/article/pii/S0099133308001742

National research foundation. (2015). Retrieved September 19, 2015, from http://www.nrf.ac.za/

Neal, J. G. (2009). What do users want? What do users need? W(h)ither the academic research library? Journal of Library Administration, 49(5), 463-468. Retrieved from http://www.tandfonline.com/doi/abs/10.1080/01930820903089104

Nel, M. (2015). Information needs, information seeking behaviour and information use behaviour of researchers at the faculty of Veterinary Science, University of Pretoria and how these needs are being met by the information support delivered by the Jotello F Soga Library, M.IS dissertation, University of Pretoria. Retrieved from http://hdl.handle.net/2263/50085 
Nel, M., \& Fourie, I. (2010). An exploratory study of the information behaviour of veterinary practitioners in South Africa. Mousaion, 28(2), 107-133. Retrieved from http://connection.ebscohost.com/c/articles/59566418/exploratory-studyinformation-behaviour-veterinary-practitioners-south-africa

Nweke, K.M.C. (1995). Information methods of human and veterinary medical scientists in Borno State, Nigeria. Library and Information Science Research, 17(1), 41-48.

Ofori-Adjei D., Antes G., Tharyan P., Slade E., Tamber, P. S. (2006). Have Online International Medical Journals Made Local Journals Obsolete? PLoS Med 3(8), e359. doi:10.1371/journal.pmed.0030359

Pantry, S. \& Griffiths, P. 2009, How to give your users the LIS services they want, London: Facet Publishing.

Pelzer, N. L., \& Wiese, W. H. (2005). Online tools for accessing veterinary information: Electronic continuing resources. Journal of Electronic Resources in Medical Libraries, 2(4), 53-79. Retrieved from http://www.tandfonline.com/doi/abs/10.1300/J383v02n04_04

Pelzer, N. L., Wiese, W. H., \& Leysen, J. M. (1998). Library use and informationseeking behavior of veterinary medical students revisited in the electronic environment. Bulletin of the Medical Library Association, 86(3), 346-355.

Pouris, A. (2007). The National Research Foundation's rating system: Why scientists let their ratings lapse. South African Journal of Science, 103(11/12), 439-441. Retrieved from http://reference.sabinet.co.za/document/EJC96632

Powell, R. R., \& Connaway, L. S. (2004). Basic research methods for librarians (4th ed.). Westport, Conn.: Libraries Unlimited.

Prakash, G. (2013). Use of internet by the researchers of Indian Veterinary Research Institute, Izzatnagar, Bareilly: A survey. Retrieved June 29, 2015 from http://digitalcommons.unl.edu/cgi/viewcontent.cgi?article=2311\&context=libphilpr ac 
Raw, M. E. (1987). Survey of libraries in veterinary practice. The Veterinary Record, 121(6), 129-131.

Ross, L., \& Sennyey, P. (2008). The library is dead, long live the library! The practice of academic librarianship and the digital revolution. The Journal of Academic Librarianship, 34(2), 145-152. Retrieved from http://www.sciencedirect.com/science/article/pii/S0099133307002492

Savolainen, R. (2007). Information behavior and information practice: Reviewing the "umbrella concepts" of information-seeking studies. The Library Quarterly, 77(2), 109-132. Retrieved from http://www.jstor.org/stable/10.1086/517840

Schmidt, D. (1992). Information resources in animal behavior. Science \& Technology Libraries, 12(1), 69-83.

Schonfeld, R. C., \& Guthrie, K. M. (2007). The changing information services needs of faculty. EDUCAUSE Review, 42(4), 8. Retrieved from https://net.educause.edu/ir/library/pdf/ERM0746.pdf

Sheeja, N. (2010). Science vs social science: A study of information-seeking behavior and user perceptions of academic researchers. Library Review, 59(7), 522-531. Retrieved from http://www.emeraldinsight.com/doi/full/10.1108/00242531011065118

Shetty, P. (2008). How to keep science local. New Scientist, 199(2664), 20. doi:10.1016/S0262-4079(08)61723-6

Shiri, A. A., \& Revie, C. (2003). The effects of topic complexity and familiarity on cognitive and physical moves in a thesaurus-enhanced search environment. Journal of Information Science, 29(6), 517-526. Retrieved from http:/jis.sagepub.com/content/29/6/517.short

Shokeen, A., \& Kumar, S. (2009). Need of library training program and importance of information sources for the veterinary scientists. Indian Journal of Animal Production and Management, 25(1/2), 38-40. 
Shumaker, D. (2011). Beyond instruction: Creating new roles for embedded librarians. In C. Kvenild \& K. Calkins (Eds.). Embedded librarians: Moving beyond one-shot instruction, (pp. 17-31). Chicago: ACRL.

Sooryamoorthy, R. (2013). Scientific research in the natural sciences in South Africa: A scientometric study. South African Journal of Science, 109(7/8), 1-11. doi: $10.1590 /$ sajs.2013/20120001

Spink, A., \& Cole, C. (2006). Human information behavior: Integrating diverse approaches and information use. Journal of the American Society for Information Science and Technology, 57(1), 25-35. Retrieved from http://onlinelibrary.wiley.com/doi/10.1002/asi.20249/abstract

Spink, A., Foster, A., \& Hepworth, M. (2007). Knowledge of information behaviour and its relevance to the design of people-centred information products and services. Journal of Documentation, 63(1), 33-56. Retrieved from http://www.emeraldinsight.com/doi/full/10.1108/00220410710723876

Swan, G. E., \& Kriek, N. (2009). Veterinary education in Africa: Current and future perspectives: Animal health management in the $21^{\text {st }}$ century. Onderstepoort Journal of Veterinary Research, 76(1), 105-114. doi: 10.4102/ojvr.v76i1.73

Talja, S. (2005). The domain analytic approach to scholars' information practices. In K. E. Fisher, S. Erdelez, L. McKechnie \& American Society for Information Science and Technology (Eds.), Theories of information behavior (pp. 123-127). Medford, N.J.: Published for the American Society for Information Science and Technology by Information Today.

Tennant, M. R. (2005). Bioinformatics librarian: Meeting the information needs of genetics and bioinformatics researchers. Reference Services Review, 33(1), 1219. Retrieved from www.emeraldinsight.com/doi/abs/10.1108/00907320410519333

Tennant, M. R., \& Cataldo, T. T. (2002). Development and assessment of specialized liaison librarian services: Clinical vs. basic science in a veterinary 
medicine setting. Medical Reference Services Quarterly, 21(2), 21-37. Retrieved from www.tandfonline.com/doi/pdf/10.1300/J115v21n02_03

Vaughan, C. L. (2008). Alternatives to the publication subsidy for research funding: Commentary. South African Journal of Science, 104(3/4), 91-96. Retrieved from http://www.scielo.org.za/scielo.php?pid=S0038$23532008000200001 \&$ script=sci_arttext

Wakeham, M., \& Garfield, D. (2005). Supporting both learning and research in a UK post-1992 university library: A case study. Journal of Librarianship and Information Science, 37(4), 175-186. doi: 10.1177/0961000605057849

Wales, T. (2000). Practice makes perfect? Vets' information seeking behaviour and information use explored. Aslib Proceedings, 52 (7), 235-246. Retrieved from www.emeraldinsight.com/doi/abs/10.1108/EUM0000000007017

Webb, J., Gannon-Leary, P., \& Bent, M. (2007). Providing effective library services for research. London: Facet.

Wilson, T. D. (2000). Human information behavior. Informing Science, 3(2), 49-56.

Wilson, T. D. (2006). Revisiting user studies and information needs. Journal of Documentation, 62(6), 680-684. Retrieved from http://www.emeraldinsight.com/doi/full/10.1108/00220410610714912

Wilson, T. D. (1981). On user studies and information needs. Journal of Documentation, 37(1), 3-15. Retrieved from http://dx.doi.org/10.1108/00220410610714895 